\title{
Anoxia/reoxygenation induces epithelial-mesenchymal transition in human colon cancer cell lines
}

\author{
MANABU OKAJIMA $^{1}$, SATOSHI KOKURA ${ }^{1,2}$, TAKESHI ISHIKAWA ${ }^{1,2}$, KATSURA MIZUSHIMA ${ }^{1}$, \\ REIKO TSUCHIYA $^{1}$, TATSUZO MATSUYAMA ${ }^{1}$, SATOKO ADACHI ${ }^{2}$, TETSUYA OKAYAMA ${ }^{1,2}$, \\ NAOYUKI SAKAMOTO ${ }^{1}$, KAZUHIRO KAMADA ${ }^{1}$, KAZUHIRO KATADA ${ }^{1}$, KAZUHIKO UCHIYAMA ${ }^{1}$, \\ OSAMU HANDA ${ }^{1}$, TOMOHISA TAKAGI ${ }^{1}$, NOBUAKI YAGI ${ }^{1}$, YUJI NAITO ${ }^{1}$ and TOSHIKAZU YOSHIKAWA $^{2}$ \\ ${ }^{1}$ Department of Molecular Gastroenterology and Hepatology, Graduate School of Medical Science, \\ Kyoto Prefectural University of Medicine; ${ }^{2}$ Department of Cancer Immuno Cell Regulation, \\ Kyoto Prefectural University of Medicine, Kyoto 602-8566, Japan
}

Received September 21, 2012; Accepted November 7, 2012

DOI: 10.3892/or.2013.2401

\begin{abstract}
Epithelial-mesenchymal transition (EMT) is considered to be a crucial event in the development of cancer metastasis. Anoxia/reoxygenation (A/R) is known to occur in cancer tissues due to angiogenesis and changes in tissue pressure that occur during tumor growth. We investigated whether A/R induces EMT in the human colon cancer cell line HT-29. Colon cancer cells were exposed to anoxia (2 h) followed by reoxygenation (4-22 h) and evaluated for EMT changes using immunofluorescence and western blot analyses. We also investigated the expression of EMT-related transcription factors (Snail and ZEB1) using RT-PCR and evaluated the expression of NF- $\kappa \mathrm{B}$ using ELISA. To determine whether $\mathrm{NF}-\kappa \mathrm{B}$ is involved in A/R-induced EMT, HT-29 cells were treated with proteasome inhibitors. Colon cancer cells exposed to A/R underwent EMT morphological changes; the cancer cells acquired a spindle-shaped phenotype. The expression of E-cadherin on the cell surface and the total amount of E-cadherin proteins were reduced after A/R. The expression of EMT-related transcription factors (Snail, ZEB1) was increased after A/R. Pretreatment with proteasome inhibitors significantly attenuated the downregulation of E-cadherin induced by $\mathrm{A} / \mathrm{R}$. These results indicate that $\mathrm{A} / \mathrm{R}$ induces $\mathrm{EMT}$ in human colon cancer cells through an NF- $\mathrm{KB}$-dependent transcriptional pathway.
\end{abstract}

Correspondence to: Dr Satoshi Kokura, Department of Molecular Gastroenterology and Hepatology, Graduate School of Medical Science, Kyoto Prefectural University of Medicine, KawaramachiHirokoji, Kamigyo-ku, Kyoto 602-8566, Japan

E-mail: s-kokura@koto.kpu-m.ac.jp

Key words: anoxia/reoxygenation, epithelial-mesenchymal transition, colon cancer, metastasis

\section{Introduction}

Distant metastasis is the major cause of death in patients with colorectal cancer (CRC). Obtaining a better understanding of the molecular mechanisms underlying distant metastasis is required in order to facilitate the development of effective therapeutic strategies for patients with CRC. In many cases of $\mathrm{CRC}$, invasion is associated with dedifferentiation of neoplastic tumor cells in invasive regions. At the invasive front of primary tumors, cancer cells can acquire a mesenchymal-like phenotype and express mesenchymal markers such as $\alpha$-SMA and vimentin, thus resembling epithelial-mesenchymal transition (EMT).

EMT plays a crucial role in gastrulation in early embryonic development and organ formation (1) and is considered to coordinate molecular steps in the process of distant metastasis. It has been reported that EMT permits both invasion and emigration in various solid tumors (2) and is associated with a poor prognosis in patients with CRC (3). EMT has been classified as a unique process in which epithelial cells undergo marked morphologic changes characterized by the transition from an epithelial cobblestone phenotype to a motile, elongated fibroblastic phenotype $(4,5)$. The hallmark of EMT is the loss of epithelial homotypic adhesion molecules such as E-cadherin and $\gamma$-catenin and the gain of mesenchymal markers such as vimentin and fibronectin. EMT is triggered by environmental stresses such as inflammation, reactive oxygen species and hypoxia (6) and is mediated intracellularly through different transcription factors, including the Snail family and Twist (7).

It is known that hypoxic or anoxic areas are heterogeneously distributed within solid tumors $(8,9)$ and tumor hypoxia can be associated with clinical responses to both chemotherapy and radiotherapy or development of metastases (10). Cancer tissues develop pathophysiological microenvironments during growth that are characterized by irregular microvascular networks and regions of chronically and transiently ischemic cells. Ischemic cancer cells are known to be reperfused by neovascularization or decreases in tissue pressure (11). Many cancer cells are exposed to anoxia/reoxygenation. 
Anoxia/reoxygenation $(\mathrm{A} / \mathrm{R})$ generates reactive oxygen species (ROS) that activate NF- $\kappa \mathrm{B} . \mathrm{A} / \mathrm{R}$ is also involved in cancer initiation, promotion and progression (12). A/R induces point mutations, deletions and gene amplification by creating oxidative damage, thereby allowing tumors to acquire malignant potential and increasing the metastatic potential (13). Moreover, it has been reported that $\mathrm{A} / \mathrm{R}$ increases the expression of VEGF and induces matrix metalloproteinase (MMP) activation, both of which are involved in tumor growth, invasion and metastasis (14-16). A/R-induced ROS may cause EMT in cancer cells; however, to date, it remains to be elucidated whether A/R induces EMT in cancer cells. Hence, the objective of this study was to clarify whether A/R induces EMT in human colon cancer cells.

\section{Materials and methods}

Cell line and cell culture. The human colon adenocarcinoma cell line HT-29 was obtained from the American Type Culture Collection (Rockville, MD). The HT-29 cells were grown in RPMI-1640 medium (Gibco BRL, Gaithersburg, MD) supplemented with $10 \%$ fetal calf serum (FCS) and penicillin $(100 \mathrm{U} / \mathrm{ml}) /$ streptomycin $(100 \mu \mathrm{g} / \mathrm{ml})$. The cell cultures were maintained in a humidified atmosphere of $95 \%$ air and $5 \% \mathrm{CO}_{2}$ at $37^{\circ} \mathrm{C}$.

Reagents and antibodies. All chemicals were prepared immediately before use. Lactacystin was purchased from Biomol International L.P. (Farmingdale, NY), MG-132 was purchased from Cayman Chemical Co. (Ann Arbor, MI) and anti-E-cadherin antibodies were purchased from Wako Pure Chemical (Osaka, Japan).

Anoxia/reoxygenation protocol. The in vitro model of anoxia/ reoxygenation used in this study is similar to a previously described model $(5,17)$. Briefly, the medium was changed to RPMI only just before the experiment was conducted, and then confluent HT-29 colon cancer cells were exposed to anoxia by incubation in a Plexiglass chamber that was continuously purged $(1 \mathrm{l} / \mathrm{min})$ with an anoxic gas mixture $\left(95 \% \mathrm{~N}_{2}-5 \% \mathrm{CO}_{2}\right)$. The chamber $\mathrm{pO}_{2}$ level was monitored during the entire experiment using an oxygen electrode (model OM-1, Microelectrodes, Londonderry, $\mathrm{NH}$ ). Reoxygenation was performed by exposing the cancer cells to normoxia $\left(21 \% \mathrm{O}_{2}-5 \% \mathrm{CO}_{2}-74 \% \mathrm{~N}_{2}\right)$ in a $\mathrm{CO}_{2}$ incubator. The control cells were exposed to normoxia.

Morphologic analysis. Phase-contrast microscopy was undertaken using CKX41 (Olympus, Tokyo, Japan) at x100 magnification. The images were captured using the Flovel Filing System (Flovel, Tokyo, Japan).

Immunocytochemistry. The HT-29 cells cultured on 35-mm $\mu$-dishes (iBidi, Munich, Germany) were incubated with the primary antibodies (anti-E-cadherin antibodies, Wako Pure Chemical) in phosphate-buffered saline (PBS) containing 5\% FCS and $2 \mathrm{mM} \mathrm{CaCl}_{2}$ for $2 \mathrm{~h}$ at room temperature followed by $30 \mathrm{~min}$ of incubation with fluorescence-labeled secondary antibodies (Alexa Fluor 594, Life Technologies, Tokyo, Japan) visualized using epi-illumination on a laser scanning confocal microscope (Olympus).
Western blotting. Whole-cell extracts were prepared as follows. The HT-29 cells were retrieved with a cell scraper and collected by centrifugation at $2,500 \mathrm{rpm} / \mathrm{min}$ at $4^{\circ} \mathrm{C}$ for $5 \mathrm{~min}$. After removing the upper PBS, the cell pellets were lysed in lysis buffer (CelLytic M; Sigma-Aldrich Co., St. Louis, MO), stirred and incubated on ice for $15 \mathrm{~min}$. The supernatants were collected and stored at $-80^{\circ} \mathrm{C}$.

The total proteins were mixed with an SDS sample buffer. The samples were then subjected to $10 \%$ SDS-PAGE and blotted onto a polyvinylidene fluoride membrane (Atto Corporation, Tokyo, Japan). The membrane was then incubated with $10 \%$ EzBlock (Atto Corporation) in TBS-T $(10 \mathrm{mM}$ Tris-Cl, $\mathrm{pH} 8.0 ; 150 \mathrm{mM} \mathrm{NaCl}, 0.1 \%$ Tween-20 v/v) for $30 \mathrm{~min}$ at room temperature and washed with TBS-T three times. The membrane was incubated for $1 \mathrm{~h}$ at room temperature with the primary antibodies (anti-human E-cadherin IgG, mouse monoclonal, Wako Pure Chemical) in TBS-T (diluted 1:500) and then incubated with the secondary anti-mouse $\operatorname{IgG}$ antibodies (GE Healthcare, Tokyo, Japan) in TBS-T (diluted 1:1000) for $1 \mathrm{~h}$ at room temperature. Immunocomplexes were detected using western blotting (ECL Plus; GE Healthcare Bio-Sciences K.K., Tokyo, Japan).

RNA isolation and quantitative RT-PCR. The expression levels of E-cadherin, vimentin, Snail and ZEB1 mRNA were determined using real-time PCR. The samples used for mRNA isolation were removed from the colon cancer cells (HT29). Total RNA was isolated using the acid guanidinium phenol chloroform method with Isogen (Nippon Gene Co. Ltd., Tokyo, Japan). The isolated RNA was stored at $-70^{\circ} \mathrm{C}$ until use in realtime PCR. In the latter, $1 \mu \mathrm{g}$ of extracted RNA was reverse-transcribed into first-strand complementary DNA (cDNA) using the High Capacity cDNA Reverse Transcription kit (Applied Biosystems, Foster City, CA). Real-time PCR for E-cadherin, vimentin, Snail, ZEB-1 and GAPDH was performed using the 7300 Real-time PCR system (Applied Biosystems) using the DNA-binding dye $\mathrm{SYBR}^{\circledR}$ Green to detect the PCR products. The primers had the following sequences: E-cadherin, sense 5'-GTCAGTTCAGACTCCAG CCC-3' and antisense 5'-AAATTCACTCTGCCCAGG ACG-3'; vimentin, sense 5'-TCTACGAGGAGGAGATGC GG-3' and antisense 5'-GGTCAAGACGTGCCAGAGAC-3'; Snail, sense 5'-ACCACTATGCCGCGCTCTT-3' and antisense 5'-GGTCGTAGGGCTGCTGGAA-3'; ZEB-1, sense 5'-TGGG ATCAACCACCAATGG-3' and antisense 5'-AAGTAACCC TGTGTATTTCTGGATGA-3'; GAPDH, sense 5'-ACCACA GTCCATGCCATCACT-3' and antisense 5'-CCATCACGC CACAGTTTCC-3'.

ELISA assay for $N F-\kappa B$ activation. Nuclear extracts were prepared using the Nuclear Extract kit (Active Motif, Tokyo, Japan). The DNA-binding activity of the p65 and p50 NF- $\mathrm{kB}$ subunits in the nuclear extracts was measured using the TransAM NF-kB p50, p52, p65 and Family kit (Active Motif) at $490 \mathrm{~nm}$ according to the manufacturer's instructions. The results were expressed as the optical density (OD).

Statistical analysis. All analyses were performed using the GraphPad Prism 4 program (GraphPad Software Inc., San Diego, CA). The results are presented as the mean \pm SEM. 

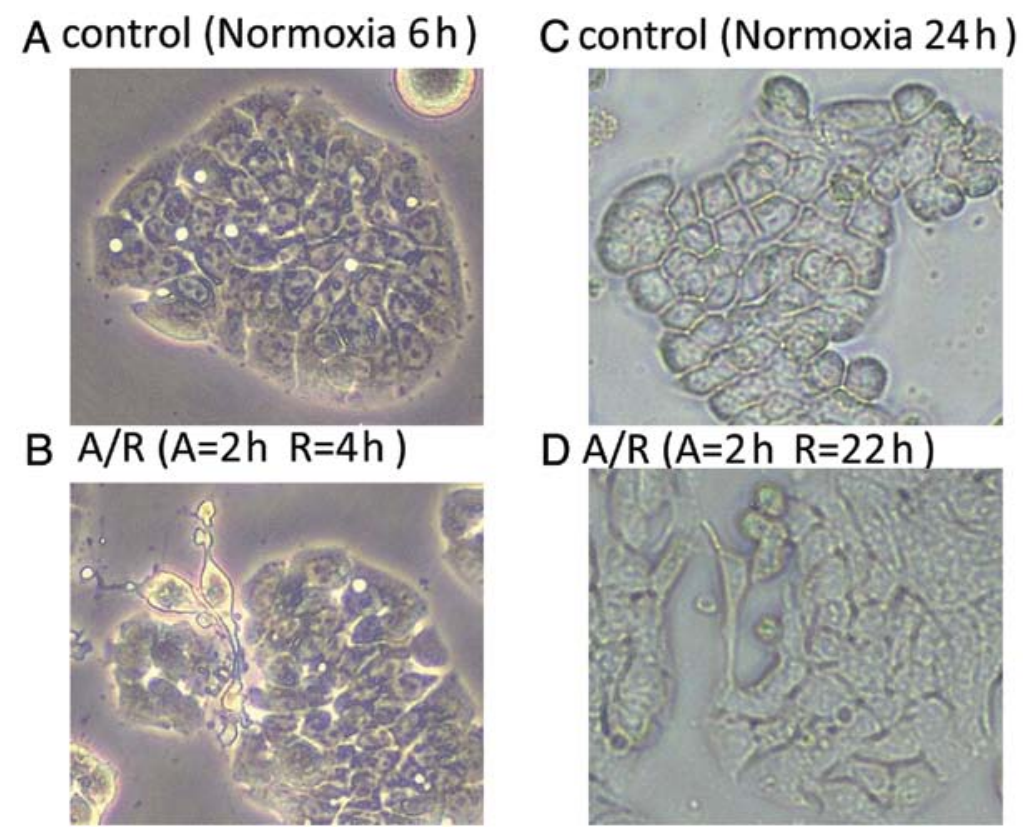

$D A / R(A=2 h R=22 h)$

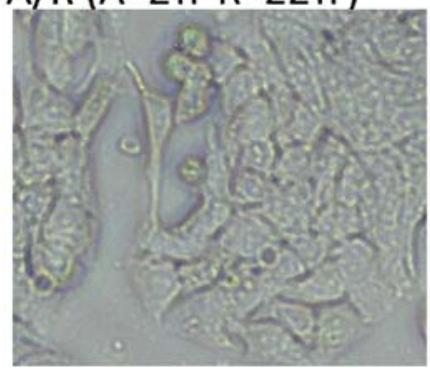

Figure 1. Stimulation with 2 h of anoxia followed by 4 or 22 h of reoxygenation induced morphologic changes consistent with EMT in HT29 cells. The cells exposed to A/R began to lose cell contact and acquired an elongated, fusiform morphology with dendritic processes, consistent with mesenchymal transition (original magnification, $\mathrm{x} 100$ ).

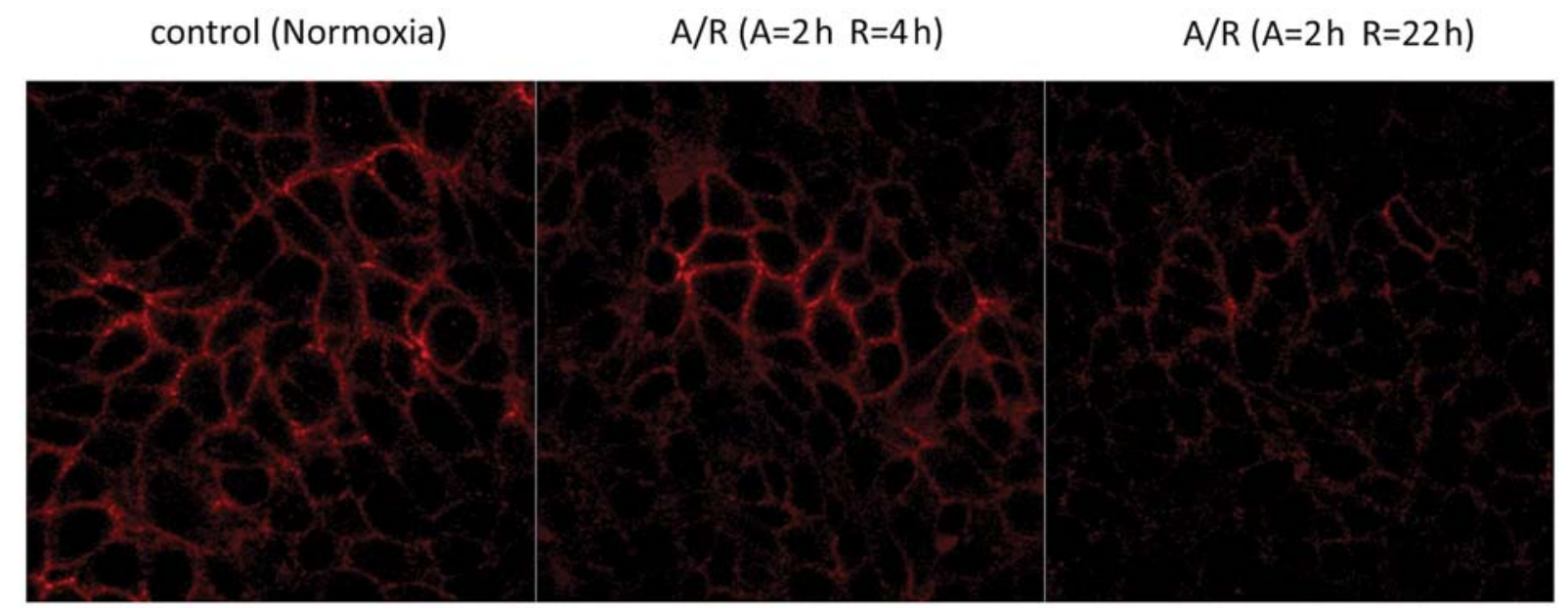

Figure 2. Immunofluorescent staining showed that the control cells exposed to normoxia were attached tightly to each other, and their E-cadherin was localized to the lateral aspects of the plasma membranes in a continuous, linear staining pattern. After 4 and $22 \mathrm{~h}$ of reoxygenation, the staining pattern for E-cadherin was altered. The previously seen linear staining pattern appeared to be weaker and discontinuous.

An analysis of variance (ANOVA) and Student's t-test were used to compare the mean values. The criterion for statistical significance was taken as $\mathrm{P}<0.05$.

\section{Results}

Anoxia/reoxygenation induces morphologic changes consistent with EMT in HT-29 cells. HT-29 cells were exposed to 6 or $24 \mathrm{~h}$ of normoxia and $2 \mathrm{~h}$ of anoxia followed by 4 or $22 \mathrm{~h}$ of reoxygenation, respectively. A phase contrast analysis (original magnification: x100) was used to detect morphological changes in HT29 cells under normoxic or A/R conditions. The cells exposed to $\mathrm{A} / \mathrm{R}$ began to lose cell contact and acquired an elongated, fusiform morphology with dendritic processes, consistent with mesenchymal transition (Fig. 1).
Expression of E-cadherin on the cell surface after anoxial reoxygenation (immunofluorescence). In the control cells exposed to normoxia, immunofluorescent staining showed that the expression of E-cadherin was localized to the lateral aspects of the plasma membranes in a continuous, linear staining pattern. In the cells exposed to $2 \mathrm{~h}$ of anoxia followed by 4 or $22 \mathrm{~h}$ of reoxygenation, the linear staining pattern appeared to be weaker (Fig. 2).

Effects of anoxia/reoxygenation on molecular markers of EMT. Quantitative RT-PCR of the E-cadherin and vimentin mRNA expression in HT29 cells was performed after 6 or $24 \mathrm{~h}$ of normoxia and $2 \mathrm{~h}$ of anoxia followed by 4 or $22 \mathrm{~h}$ of reoxygenation. Two hours of anoxia followed by $4 \mathrm{~h}$ of reoxygenation significantly downregulated the expression of 
A

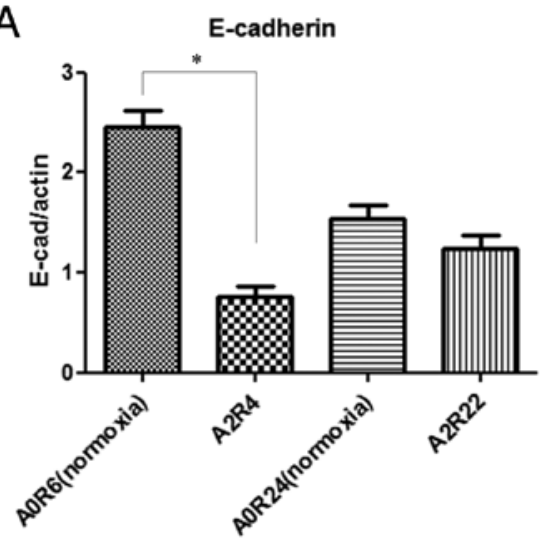

B E-cadherin

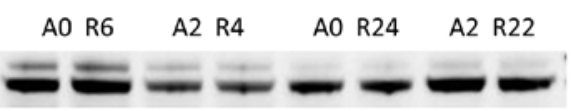

Vimentin

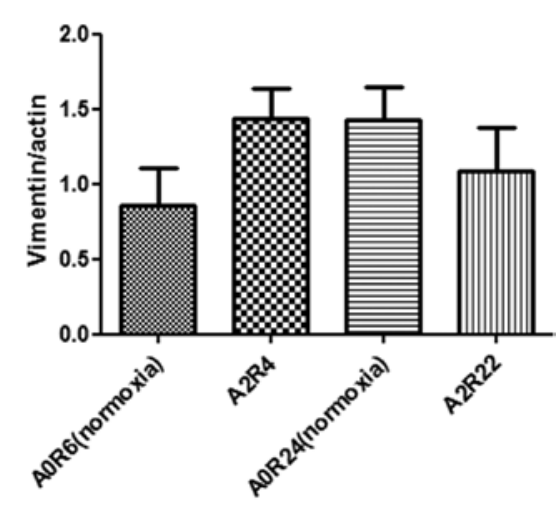

Figure 3. (A) E-cadherin and vimentin mRNA expression in HT-29 cells. Total RNA was extracted from the normoxia (6 h or 24 h)-exposed HT-29 cells and the anoxia $(2 \mathrm{~h}$ )/reoxygenation ( $4 \mathrm{~h}$ or $22 \mathrm{~h}$ )-exposed HT-29 cells. RNA was reverse-transcribed and subjected to real-time quantitative amplification to determine the levels of each mRNA in the HT-29 cells. Each value represents the mean \pm SEM of four experiments. * $<<0.05$. (B) Cell lysates were extracted from the normoxia ( $6 \mathrm{~h}$ or $24 \mathrm{~h}$ )-exposed HT-29 cells and the anoxia ( $2 \mathrm{~h})$ /reoxygenation ( $4 \mathrm{~h}$ or $22 \mathrm{~h})$-exposed HT-29 cells and subjected to western blotting.

snail

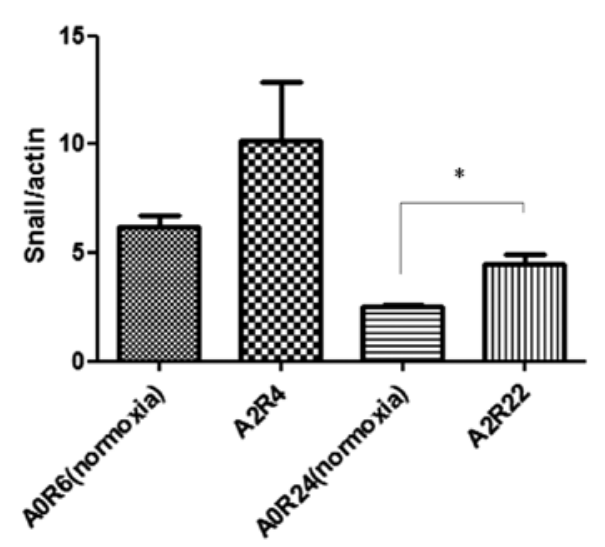

ZEB1

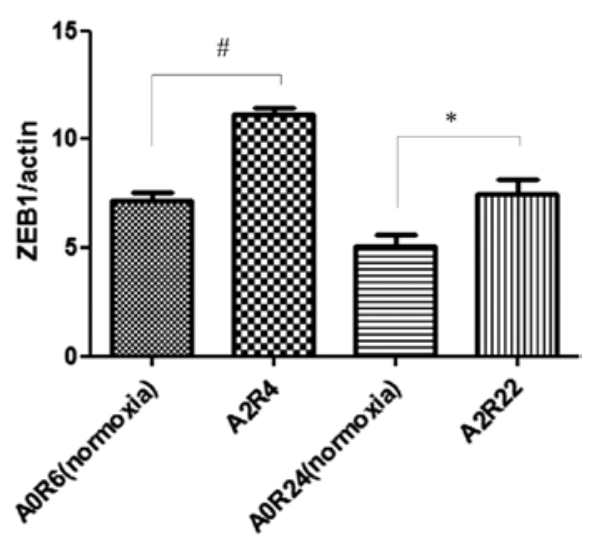

Figure 4. Snail and ZEB1 mRNA expression in the HT-29 cells. Total RNA was extracted from the normoxia (6 h or $24 \mathrm{~h})$-exposed HT-29 cells and the anoxia $(2 \mathrm{~h})$ /reoxygenation $(4 \mathrm{~h}$ or $22 \mathrm{~h}$ )-exposed HT-29 cells. RNA was reverse-transcribed and subjected to real-time quantitative amplification to determine the levels of each mRNA in the HT-29 cells. Each value represents the mean \pm SE of four experiments. ${ }^{*} \mathrm{P}<0.05,{ }^{*} \mathrm{P}<0.05$.

E-cadherin mRNA and tended to upregulate the expression of vimentin mRNA (Fig. 3A).

Western blotting was performed on the cell lysates obtained from the anoxia/reoxygenation-exposed HT-29 cells. No significant losses of E-cadherin were detectable after $2 \mathrm{~h}$ of anoxia followed by $22 \mathrm{~h}$ of reoxygenation relative to that observed after $6 \mathrm{~h}$ of normoxia. In contrast, a clear and consistent reduction in the total amount of E-cadherin was seen after $2 \mathrm{~h}$ of anoxia followed by $4 \mathrm{~h}$ of reoxygenation relative to that observed after $6 \mathrm{~h}$ of normoxia (Fig. 3B).

Quantitative RT-PCR of the Snail and ZEB-1 mRNA expression in HT29 cells was performed after 6 or 24 h of normoxia and $2 \mathrm{~h}$ of anoxia followed by 4 or $22 \mathrm{~h}$ of reoxygenation. Two hours of anoxia followed by 4 or $22 \mathrm{~h}$ of reoxygenation upregulated both Snail and ZEB-1 mRNA (Fig. 4). These results indicate that stimulation with $2 \mathrm{~h}$ of anoxia followed by $4 \mathrm{~h}$ of reoxygenation induces EMT to a greater extent than stimulation with $2 \mathrm{~h}$ of anoxia followed by $22 \mathrm{~h}$ of reoxygenation. Therefore, subsequent experiments were performed under A/R conditions with $2 \mathrm{~h}$ of anoxia followed by $4 \mathrm{~h}$ of reoxygenation.

\section{Comparison of the effects of anoxia and anoxia/reoxygenation} on molecular markers of EMT. Quantitative RT-PCR of the E-cadherin and vimentin mRNA expression in HT29 cells was performed after $6 \mathrm{~h}$ of anoxia and $2 \mathrm{~h}$ of anoxia followed by $4 \mathrm{~h}$ of reoxygenation. Two hours of anoxia followed by $4 \mathrm{~h}$ of reoxygenation significantly downregulated E-cadherin mRNA and tended to upregulate vimentin mRNA (Fig. 5A).

Quantitative RT-PCR of the Snail and ZEB-1 mRNA expression in HT29 cells was performed after $6 \mathrm{~h}$ of anoxia and $2 \mathrm{~h}$ of anoxia followed by $4 \mathrm{~h}$ of reoxygenation. Two hours of anoxia followed by $4 \mathrm{~h}$ of reoxygenation upregulated both Snail and ZEB-1 mRNA (Fig. 5B). These results indicate that stimulation with $2 \mathrm{~h}$ of anoxia followed by $4 \mathrm{~h}$ of reoxygenation 
A

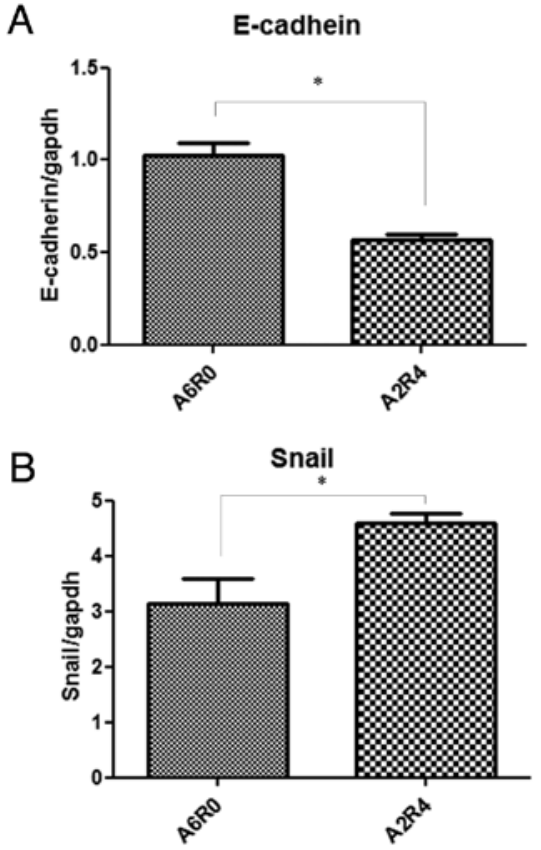

Vimentin

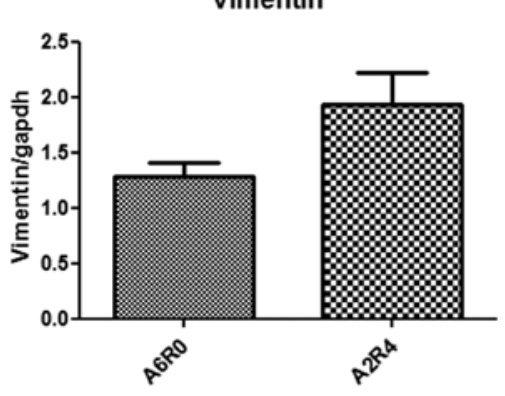

ZEB-1

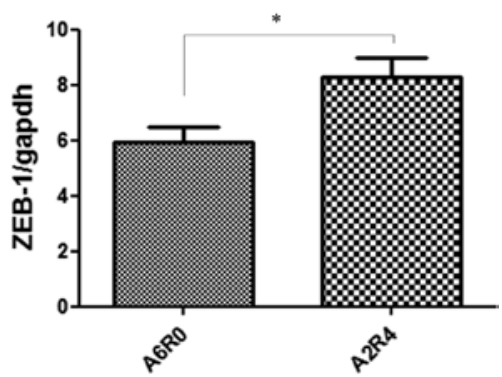

Figure 5. (A) E-cadherin and vimentin mRNA expression in the HT-29 cells. Total RNA was extracted from the anoxia (6 h)-exposed HT-29 cells and the anoxia $(2 \mathrm{~h}$ )/reoxygenation (4 h)-exposed HT-29 cells. RNA was reverse-transcribed and subjected to real-time quantitative amplification to determine the levels of each mRNA in the HT-29 cells. Each value represents the mean \pm SEM of four experiments. ${ }^{*} \mathrm{P}<0.05$. (B) Snail and ZEB1 mRNA expression in the HT-29 cells. Total RNA was extracted from the anoxia (6 h)-exposed HT-29 cells and the anoxia ( $2 \mathrm{~h}$ )/reoxygenation (4 h)-exposed HT-29 cells. RNA was reverse-transcribed and subjected to real-time quantitative amplification to determine the levels of each mRNA in the HT-29 cells. Each value represents the mean \pm SEM of four experiments. "P<0.05.
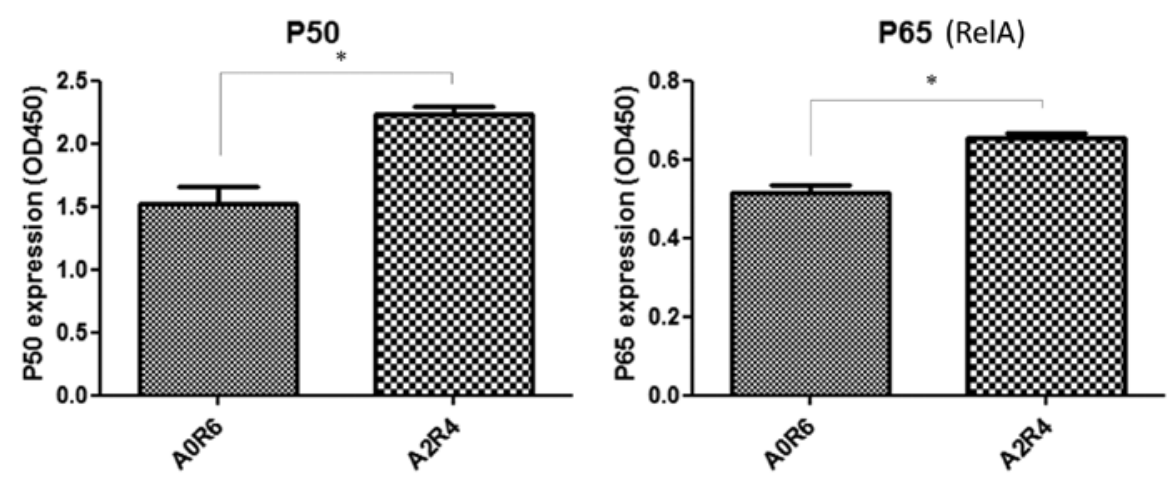

Figure 6. Nuclear extracts from the normoxia (6 h)-exposed HT-29 cells and the anoxia ( $2 \mathrm{~h}$ )/reoxygenation $(4 \mathrm{~h})$-exposed HT-29 cells were used to measure $\mathrm{NF}-\mathrm{kB}-\mathrm{p} 50$ and p65 subunit binding activity in an ELISA assay. Each value represents the mean \pm SEM of three experiments. ${ }^{*} \mathrm{P}<0.05$.

induces EMT a greater extent than stimulation with $6 \mathrm{~h}$ of anoxia.

Effects of anoxia/reoxygenation on $N F-\kappa B$ in $H T 29$ cells (ELISA). Nuclear proteins were extracted from HT29 cells after $2 \mathrm{~h}$ of anoxia followed by $4 \mathrm{~h}$ of reoxygenation and $6 \mathrm{~h}$ of normoxia. The optical density (OD) exhibited by the active forms of p50 and p65 proteins in the nuclear extracts of the HT29 cells was significantly increased after $2 \mathrm{~h}$ of anoxia followed by $4 \mathrm{~h}$ of reoxygenation compared to that observed after $6 \mathrm{~h}$ of normoxia (Fig. 6).

Effects of inhibition of $N F-\kappa B$ activation (proteasome inhibitor) on the transcription of E-cadherin after anoxial reoxygenation ( $R T-P C R)$. To evaluate the contribution of the transcription factor NF- $\kappa \mathrm{B}$ on anoxia/reoxygenation-induced downregulation of E-cadherin, HT-29 cells were treated with proteasome inhibitors (lactacystin or MG132). Treatment with the proteasome inhibitors alone had no significant effects on the expression of E-cadherin (data not shown). HT-29 cells were pretreated with lactacystin $(10 \mu \mathrm{M})$ or MG132 $(10 \mu \mathrm{M})$ for $1 \mathrm{~h}$. Quantitative RT-PCR of the E-cadherin mRNA expression in HT29 cells was performed after $6 \mathrm{~h}$ of normoxia and $2 \mathrm{~h}$ of anoxia followed by $4 \mathrm{~h}$ of reoxygenation. Decreases in the E-cadherin mRNA expression were attenuated when the cells were pretreated with lactacystin or MG132 (Fig. 7).

\section{Discussion}

Transient cycles of $\mathrm{A} / \mathrm{R}$ are known to occur within solid tumors and can be associated with metastatic development (11). Although it has been reported that various environmental 


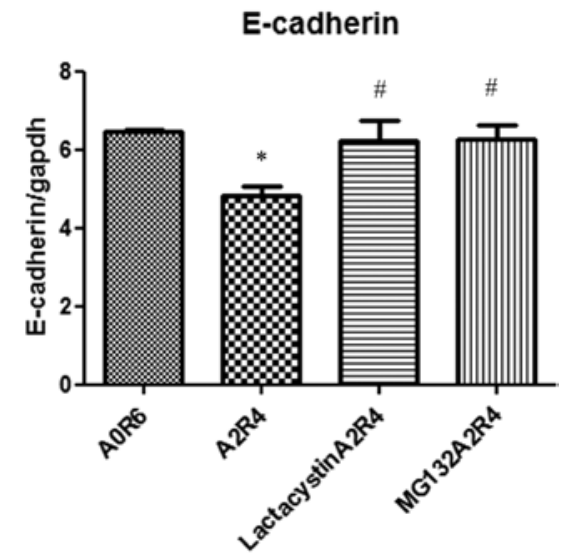

Figure 7. Effects of lactacystin $(10 \mu \mathrm{M})$ or MG132 $(10 \mu \mathrm{M})$. Responses are shown for E-cadherin expression at $4 \mathrm{~h}$ of reoxygenation after anoxia ( $2 \mathrm{~h}$ ). Each value represents the mean \pm SEM of four experiments. ${ }^{*} \mathrm{P}<0.05$ compared with normoxia. " $\mathrm{P}<0.05$ compared with $4 \mathrm{~h}$ of reoxygenation after anoxia.

stressors such as inflammation and hypoxia can induce EMT, the effects of $\mathrm{A} / \mathrm{R}$ stress on EMT have not yet been clarified. In this study, we showed that $\mathrm{A} / \mathrm{R}$ stress induces morphologic and molecular alterations consistent with EMT in human colon cancer cells. Furthermore, we showed that activation of nuclear factor NF- $\mathrm{\kappa B}$ is a critical event in A/R-induced EMT since A/R-induced EMT was abolished almost completely by pretreatment with proteasome inhibitors. This study is the first report demonstrating that $\mathrm{A} / \mathrm{R}$ stress can strongly induce EMT in colon cancer cells.

Hypoxia is a common condition found in various solid tumors and can be associated with resistance to chemotherapy and radiation therapy. Ischemic regions can exhibit intermittent reflow and associated redox stress $(8,18)$. It has been shown that cycling through periods of acute hypoxia followed by reoxygenation leads to the promotion of tumor cell survival (19) and increased metastatic development (20). Maqat et al, using the ${ }^{19} \mathrm{~F}$ MRI technique, recently demonstrated that spontaneous fluctuations in tumor $\mathrm{pO}_{2}$ occur regardless of the basal oxygenation state (i.e., in both oxygenated and hypoxic regions) (11). In addition, it has been reported that hypoxia (anoxia)/reoxygenation occurs in tumors $(8,9,13)$. Hypoxia (anoxia)/reoxygenation stress leads to the generation of a large amount of ROS from the mitochondria, and redox alterations modulate various mitogenic and survival signaling pathways, including NF- $\mathrm{KB}$ activation, and contribute to cancer cell proliferation and invasion (12). Although A/R-induced ROS generation and/or NF- $\kappa$ B activation may cause EMT in cancer cells, this issue has not been addressed to date.

EMT not only plays crucial roles in the formation of the body plan and physiological responses to injury, but also is an important element in cancer progression $(1,21-23)$. The process of EMT involves the loss of epithelial cell-cell junction and upregulation of mesenchymal markers such as vimentin and fibronectin. Epithelial cancer cells acquire migratory and invasive properties during the EMT process. It has been reported that EMT-inducing signals emanating from the tumor-associated stroma, notably HGF (hepatocyte growth factor), EGF, PDGF and TGF- $\beta$, are responsible for the induction of a series of EMT-inducing transcription factors such as Snail, Slug, zinc finger E-box binding homeobox 1 (ZEB1) and Twist $(22,24,25)$. Multiple lines of evidence indicate that these EMT-inducing transcription factors are regulated either directly or indirectly by NF- $\mathrm{KB}(5,26-28)$. We and others have indicated that $\mathrm{A} / \mathrm{R}$ stress generates a large amount of intracellular ROS and rapidly and strongly activates NF- $\kappa \mathrm{B}(12,29)$. In agreement with the results of these previous studies, there were greater amounts of intracellular ROS generation under the $\mathrm{A} / \mathrm{R}$ conditions than under normoxia or anoxia (data not shown), and NF- $\mathrm{kB}$ activity was significantly enhanced under the $A / R$ conditions compared to that observed under the normoxic conditions.

Recent studies have demonstrated that hypoxia and the overexpression of hypoxia-inducible factor-1a (HIF-1 $\alpha$ ) promotes EMT in tumor cells $(30,31)$. In the present study, A/R promoted EMT more strongly than hypoxia alone in a short period of stress time (6h). We found that EMT changes (fibroblastoid phenotype, Snail transcription and changes in E-cadherin) appeared within $6 \mathrm{~h}$ after A/R treatment, whereas other studies demonstrated that EMT changes induced by hypoxia are detected 24 to $72 \mathrm{~h}$ from the beginning of hypoxia (32). Cannito et al demonstrated that hypoxia-dependent EMT changes occur through a biphasic mechanism. Early EMT-related events induced by hypoxia (GSK-3 $\beta$ inhibition and Snail translocation) are dependent on the transient intracellular increased generation of ROS. Later EMT-related events (migration and invasiveness) are sustained by HIF-1 $\alpha$ - and vascular endothelial growth factor (VEGF)dependent mechanisms (32). It has been demonstrated that acutely and chronically hypoxic cells coexist in solid tumors, and the fraction of acutely hypoxic cells is larger than the fraction of chronically hypoxic cells (33). Therefore, in solid tumors, A/R stress may play a more important role than hypoxic stress in inducing EMT. A/R occurs repeatedly in solid tumors (11), and $\mathrm{A} / \mathrm{R}$ cycles can induce EMT and have been implicated in invasion and metastasis. Moreover, it is possible that a large amount of ROS induced by A/R is a strong trigger for EMT, and VEGF and HIF-1 $\alpha$ expressed under hypoxic conditions may contribute to maintaining the EMT phenotype. Conducting in vivo animal studies is required to clarify the mechanisms underlying the effects of fluctuations in tumor blood flow on EMT induction.

In conclusion, $\mathrm{A} / \mathrm{R}$ rapidly and strongly induces EMT in human colon cancer cells (HT29) via the NF- $\mathrm{kB}$-dependent transcriptional pathway. These observations strongly suggest that $\mathrm{A} / \mathrm{R}$ stress plays a pathogenic role in tumor progression by inducing EMT. A/R-induced molecules, such as NF- $\mathrm{KB}$ and ROS, may therefore be good targets for inhibiting A/R-induced EMT and invasiveness in colonic cancer therapy.

\section{Acknowledgements}

This study was partially supported by JSPS KAKENHI Grant no. 23590891 . S.K., T.I. and T.O. are affiliated with a donationfunded department from Takara Bio Inc. Y.N. received scholarship funds from Otsuka Pharmaceutical Co., Ltd. and Takeda Pharmaceutical Co., Ltd.

\section{References}

1. Greenburg G and Hay ED: Epithelia suspended in collagen gels can lose polarity and express characteristics of migrating mesenchymal cells. J Cell Biol 95: 333-339, 1982. 
2. Kalluri R and Weinberg RA: The basics of epithelial-mesenchymal transition. J Clin Invest 119: 1420-1428, 2009.

3. Spaderna S, Schmalhofer O, Hlubek F, Berx G, Eqer A, Merkel S, et al: A transient, EMT-linked loss of basement membranes indicates metastasis and poor survival in colorectal cancer. Gastroenterology 131: 830-840, 2006.

4. Hugo H, Ackland ML, Blick T, Lawrence MG, Clements JA Williams ED, et al: Epithelial-mesenchymal and mesenchymalepithelial transitions in carcinoma progression. J Cell Physiol 213: 374-383, 2007.

5. Min C, Eddy SF, Sherr DH and Sonenshein GE: NF- $\kappa B$ and epithelial to mesenchymal transition of cancer. J Cell Biochem 104: 733-744, 2008

6. Wang Y and Zhou BP: Epithelial-mesenchymal transition in breast cancer progression and metastasis. Chin J Cancer 30: 603-611, 2011.

7. Jouppila-Mättö A, Närkiö-Mäkelä M, Soini Y, Pukkila M, Sironen $\mathrm{R}$, Tuhkanen $\mathrm{H}$, et al: Twist and snail expression in pharyngeal squamous cell carcinoma stroma is related to cancer progression. BMC Cancer 11: 350, 2011.

8. Okunieff P, Fenton B and Chen Y: Past, present, and future of oxygen in cancer research. Adv Exp Med Biol 566: 213-222, 2005

9. Vaupel P, Schlenqer K, Knoop C and Hockel M: Oxygenation of human tumors: evaluation of tissue oxygen distribution in breast cancers by computerized $\mathrm{O}_{2}$ tension measurements. Cancer Res 51: 3316-3322, 1991.

10. Fokas E, McKenna WG and Muschel RJ: The impact of tumor microenvironment on cancer treatment and its modulation by direct and indirect antivascular strategies. Cancer Metastasis Rev 31: 823-842, 2012.

11. Maqat J, Jordan BF, Cron GO and Gallez B: Noninvasive mapping of spontaneous fluctuations in tumor oxygenation using ${ }^{19} \mathrm{~F}$ MRI. Med Phys 37: 5434-5441, 2010.

12. Morgan MJ and Liu ZG: Crosstalk of reactive oxygen species and NF- $\mathrm{BB}$ signaling. Cell Res 21: 103-115, 2011.

13. Rofstad EK: Microenvironment-induced cancer metastasis. Int J Radiat Biol 76: 589-605, 2000.

14. Binker MG, Binker-Cosen AA, Richards D, Gaisano HY, de Cosen RH and Cosen-Binker LI: Hypoxia-reoxygenation increase invasiveness of PANC-1 cells through Rac1/MMP-2. Biochem Biophys Res Commun 393: 371-376, 2010.

15. Nicould IB, Jones CM, Pierce JM, Earl TM, Matrisian LM, Chari RS, et al: Warm hepatic ischemia-reperfusion promotes growth of colorectal carcinoma micrometastases in mouse liver via matrix metalloproteinase-9 induction. Cancer Res 67: 2720-2728, 2007.

16. Man K, Nq KT, Lo CM, Ho JW, Sun BS, Sun CK, et al: Ischemiareperfusion of small liver remnant promotes liver tumor growth and metastases - activation of cell invasion and migration pathways. Liver Transpl 13: 1669-1677, 2007.

17. Kokura S, Yoshida N, Imamoto E, Ueda M, Ishikawa $T$, Uchiyama K, Kuchide M, Naito Y, Okanoue T and Yoshikawa T: Anoxia reoxygenation down-regulates the expression of E-cadherin in human colon cancer cell lines. Cancer Lett 211: $79-87,2004$
18. Teicher BA: Hypoxia and drug resistance. Cancer Metastasis Rev 13: 139-168, 1994.

19. Martinive P, Defresne F, Bouzin C, Saliez J, Lair F, Grégoire V, et al: Preconditioning of the tumor vasculature and tumor cells by intermittent hypoxia: implications for anticancer therapies. Cancer Res 66: 11736-11744, 2006.

20. Cairns RA, Kalliomaki T and Hill RP: Acute (cyclic) hypoxia enhances spontaneous metastasis of KHT murine tumors. Cancer Res 61: 8903-8908, 2001

21. Jing Y, Han Z,Zhang S, Liu Y and Wei L: Epithelial-mesenchymal transition in tumor microenvironment. Cell Biosci 1: 29, 2011.

22. Thiery JP: Epithelial-mesenchymal transitions in tumor progression. Nat Rev Cancer 2: 442-454, 2002.

23. Lee MY and Shen MR: Epithelial-mesenchymal transition in cervical carcinoma. Am J Transl Res 4: 1-13, 2012.

24. Shi Y and Massagué J: Mechanisms of TGF-beta signaling from cell membrane to the nucleus. Cell 113: 685-700, 2003.

25. Medici D, Hay ED and Olsen BR: Snail and Slug promote epithelial-mesenchymal transition through beta-catenin-T-cell factor-4-dependent expression of transforming growth factorbeta3. Mol Biol Cell 19: 4875-4887, 2008.

26. Bachelder RE, Yoon SO, Franci C, de Herreros AG and Mercurio AM: Glycogen synthase kinase-3 is an endogenous inhibitor of Snail transcription: implications for the epithelialmesenchymal transition. J Cell Biol 168: 29-33, 2005.

27. Chua HL, Bhat-Nakshatri P, Clare SE, Morimiya A, Badve S and Nakashatri H: NF-kappaB represses E-cadherin expression and enhances epithelial to mesenchymal transition of mammary epithelial cells: potential involvement of ZEB-1 and ZEB-2. Oncogene 26: 711-724, 2007.

28. Takeda K, Takeuchi O, Tsujimura T, Itami S, Adachi O, Kawai T, et al: Limb and skin abnormalities in mice lacking IKKalpha. Science 284: 313-316, 1999.

29. Rupec RA and Baeuerle PA: The genomic response of tumor cells to hypoxia and reoxygenation. Differential activation of transcription factors AP-1 and NF-kappa B. Eur J Biochem 234: 632-640, 1995

30. Cheng ZX, Sun B, Wang SJ, Gao Y, Zhang YM, Zhou HX, et al: Nuclear factor- $\kappa \mathrm{B}$-dependent epithelial to mesenchymal transition induced by HIF-1 $\alpha$ activation in pancreatic cancer cells under hypoxic conditions. PLoS One 6: e23752, 2011.

31. Shi J, Wan Y and Di W: Effect of hypoxia and re-oxygenation on cell invasion and adhesion in human ovarian carcinoma cells. Oncol Rep 20: 803-807, 2008.

32. Cannito S, Novo E and Compaqnone A: Redox mechanisms switch on hypoxia-dependent epithelial-mesenchymal transition in cancer cells. Carcinogenesis 29: 2267-2278, 2008.

33. Rofstad EK, Galappathi K, Mathiesen B and Ruud EB: Fluctuating and diffusion-limited hypoxia-induced metastasis. Clin Cancer Res 13: 1971-1978, 2007. 